\title{
The effect of motor sequential training on language development in 4-to 8-year- old deaf children with cochlear implants
}

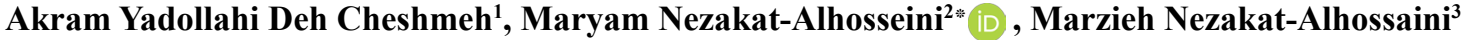 \\ 1. MS of Physical Education, Department of Physical Education, Islamic Azad University of Isfahan Branch (Khorasgan), Isfahan, Iran \\ 2. Associate Professor of Motor Behavior, Department of Sport Sciences, University of Isfahan, Isfahan, Iran \\ 3. Assistant Professor of Department of English Language, School of Management and Medical Information Sciences, Isfahan University \\ of Medical Sciences, Isfahan, Iran
}

Recieved: 21 Feb. 2018

Revised: 11 Sep. 2018

Accepted: 26 Sep. 2018

Keywords

Motor sequential training

Language development

Cochlear implant

Taekwondo

\section{Corresponding author}

Maryam Nezakat-Alhosseini, Associate Professor of Motor Behavior, Department of Sport Sciences, University of Isfahan, Isfahan, Iran

Email: Mnezakat2003@yahoo.com

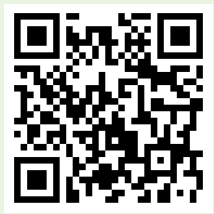

\section{Abstract}

Introduction: Sequential learning is an inseparable part of language development. Children who have difficulty to perform sequential motor tasks are poorer in the language skills as well. Therefore, the present study aimed to investigate the effect of sequential motor training on language development of children with the cochlear implant.

Methods: This study was quasi-experimental kind with pretest-posttest design, in which 22 children ( 9 girls and 13 boys) aged 4 to 8 years who were randomly selected and assigned into two groups of experimental and control. The experimental group underwent a twelve-week sequential motor training of taekwondo. Phonological awareness, reading and dyslexia tests (NEMA) were used to collect data on phonological awareness and reading performance, respectively. The data were analyzed using analysis of covariance. Results: The results showed that, after the twelve weeks of taekwondo training, the experimental group significantly outperformed the control group in phonological awareness and reading performance.

Conclusion: According to the obtained results, there seems to be a strong relationship between language and motor systems, and sequential motor training, in the case of taekwondo training, which can be an effective exercise method to improve language skills of children with the cochlear implant

Citation: Yadollahi Deh Cheshmeh A, Nezakat-Alhosseini M, Nezakat-Alhosseini M. The effect of motor sequential training on language development in 4-to 8-year-old deaf children with cochlear implants. Advances in Cognitive Sciences. 2019;21(3):42-51. 


\title{
اثر تمرينات حركتى متوالى بر رشد زبانى كودكان f Fا ^ سال ناشنوا با كاشت حلزون
}

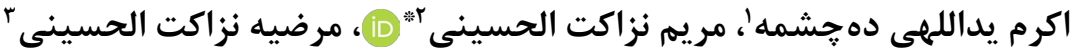
ا. كارشناسى ارشد تربيت بدنى، دانشكده تربيت بدنى، دانشكاه آزاد اسلامى اصفهان (خوراسكان)، اصفهان، ايران

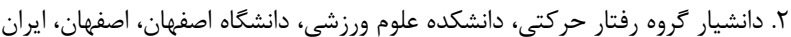

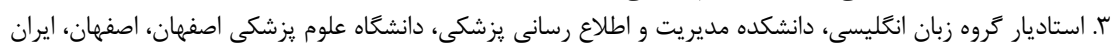

\section{ars?}

مقلدمه: يادكيرى توالى يك بخش ضرورى در رشد زبان است و كودكانى كه در اجراى تكاليف توالى حركتى مشكل دارند از نظر مهارت زبانى نيز ضعيفتر هستند. بنابراين هدف از تحقيق حاضر بررسى اثر يك دوره تمرينات حركتى متوالى بر

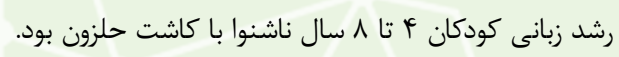

روش كار: اين يُروهش از نوع نيمه تجربى با طح بيش آزمونبِ آزمون و گروه كنترل بود. شركت كنندكان در اين

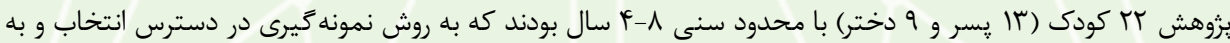
طور تصادفى در دو گروه آزمايش و كنترل كمارده شدند. سيس كروه آزمايش به مدت rا هفته تمرينات متوالى تكواندو را انجام دادند. از آزمونهاى آكاهى واج شناسى و خواندن و نارساخوانى (نما) به ترتيب جهت سنجش آكاهى واج شناسى و عملكرد خواندن استفاده شد. دادهها با استفاده از روش تحليل كوواريانس تجزيه و تحليل شدند. يافته ها: يافتهها نشان داد، يِ از rا هفته تمرينات متوالى تكواندو نمرات آحاهى واج شناسى و عملكرد خواندن كودكان كروه آزمايش نسبت به كروه كنترل به طور معنادارى بهبود يافته است (ه•/P> (P). نتيجهَّيرى: با توجه به نتايج اين مطالعه، به نظر ميرسد ارتباط قوى ميان سيستمهاى زبانى و حركتى وجود داشته باشد و تمرينات متوالى تكواندو ممكن است يك روش تمرينى مفيد براى كمك به رشد زبانى كودكان ناشنوا با كاشت حلزون باشد.

دريافت:

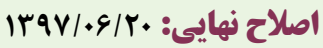

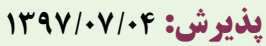

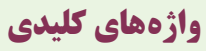
تمرينات متوالى حركتى رشد زبان كاشت حلزون تكواندو

نويسنده مسئول مريم نزاكت الحسينى، دانشيار گروه رفتار حركتى، دانشكده علوم ورزشى، دانشكاه اصفهان، اصفهان، ايران

ايميل:Mnezakat2003@yahoo.com

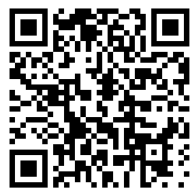

dol doi.org/10.30699/icss.21.3.42

مقلدمه

كفتار را فراهم مىنمايد. آن خه كه برقرارى اين تعاملات را امكان يذير مىسازد حس شنوايى است ( (1). هركونه ضايعهاى در سيستم شنوايى

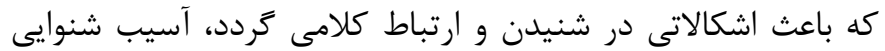
ناميده مىشود (r). اختلالات شنوايى بسته به جايخاهى كه دجار آسيب شده است، شكل و ماهيت متفاوتى دارند. با نبود بازخورد آكوسيتكى
فرايندهاى لازم براى شنيدن، ييش از رشد كامل جنين در رحم مادر به

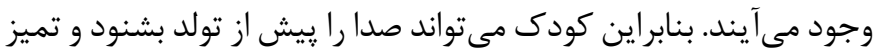
دهد. در هنگًام تولد و يس از آن، كودى آماده برخوردارى از محرك هاى زبانى و گفتارى از محيط پييرامونش مى با محيط، فرصت يردازش اصوات و به حداكثر رساندن دريافت و توليد 
مغزى مختص در يردازش زبانى و يردازش فضايى_بينايى مىشود. حتى در مطالعهاى بر روى دوقلوهايى كه يكى يا هر دو مبتلا به اختلالات

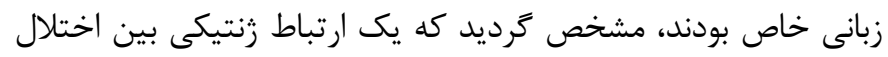

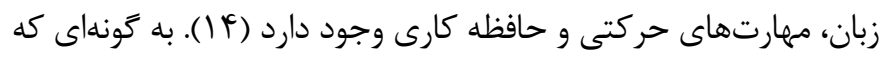

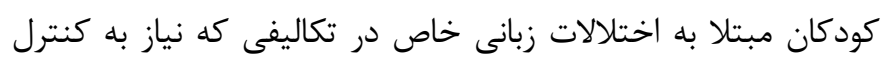

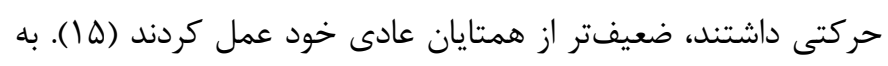

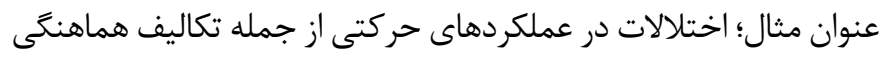

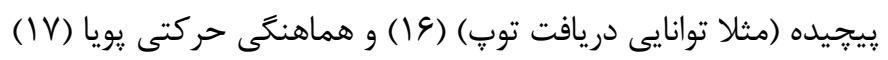
در كودكان كاشت حلزون مشاهده شده است. به عبارت ديخر كودكان ناشنوا با كاشت حلزون در اجراى تكاليف حركتى متوالى مثل پاشنه و ينجه كردن پا روى زمين، ضربه زدن با دست به سر زانو، ضربه زدن اند

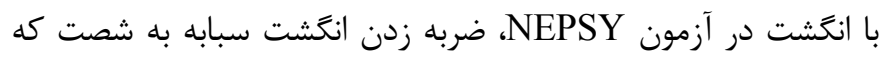

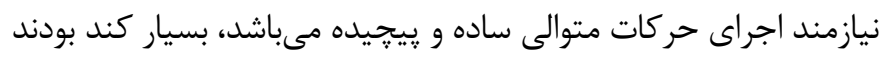

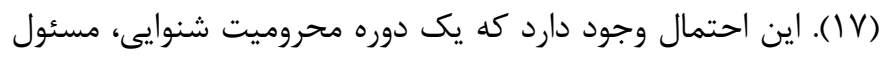

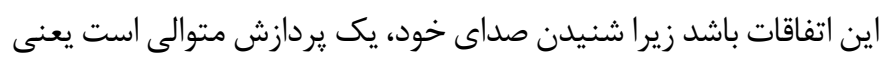

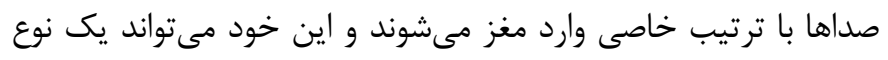

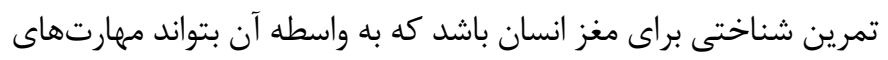

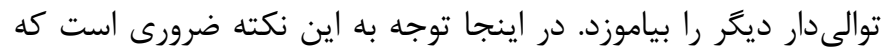

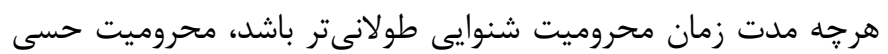

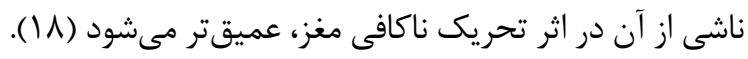

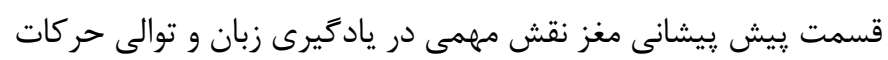

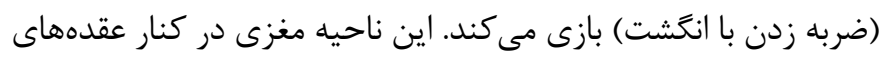

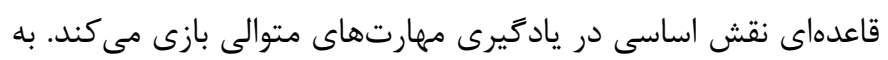

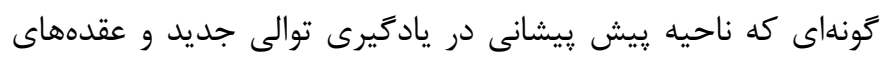

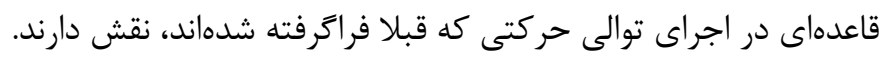
بنابراين اختلال در انجام حركات متوالى در ناشنوايان، مىتواند مربوط به اختلال در مدارهاى عصبى ناحيه پِيش پِيشانى مغز باشد. البته از نظر بيولوزيكى هم مشخص شده است كه اين نواحى در افراد ناشنوا از بلوغ كمترى برخوردارند. بنابراين محققان معتقدند كه بين يادكيرى

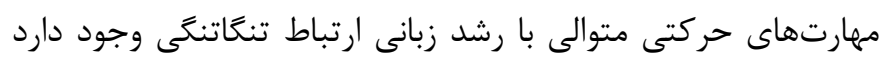

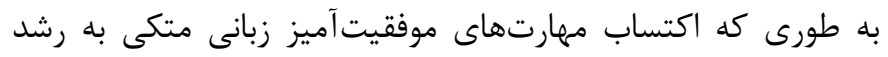

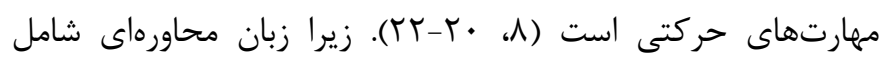

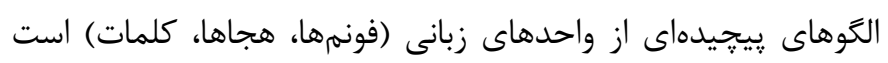

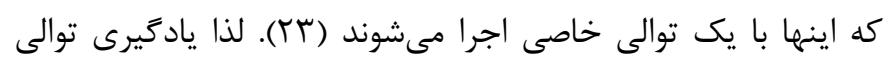
حركتى، مولفهى اساسى رشد زبان است (^، 9).

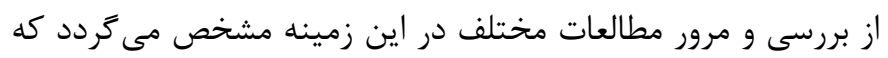

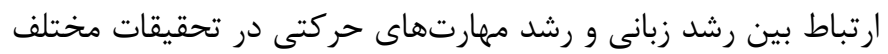

(صوت شناسى) و ناتوانى در كسب اطلاعات ضرورى شنوايى، رشد طبيعى زبان با اختلال مواجه مىشود. در اين خصوص تحريك دستگاه

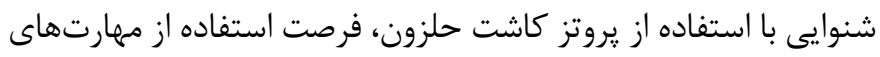

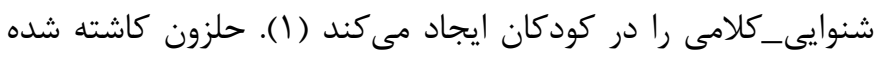

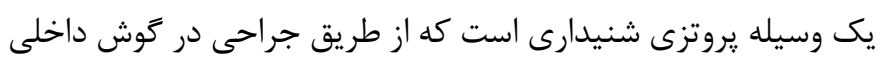

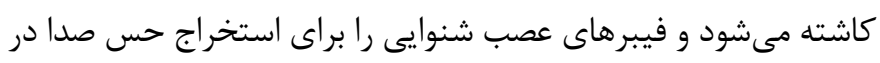
افراد مبتلا به افت شنوايى عصبى شديد و عميق تحريك مئى كند (ساى). با عمل جراحى كاشت حلزون سلولهاى مويى آسيب ديده كنار كذاشته مىشود و عصب شنوايى به طور مستقيم تحريك مىشود (\{). با توجه به اين كه رشد زبان كفتارى در سالهاى اوليه زندكى صورت مىيذيرد، سن تشخيص اختلال شنوايى و كاشت حلزون عامل مههم و تاثيركذارى

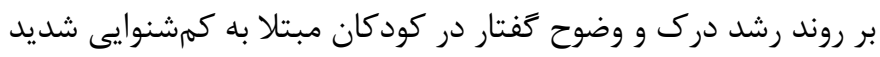

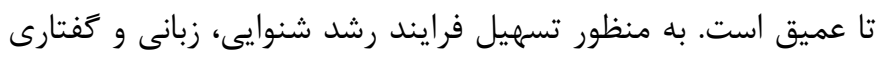

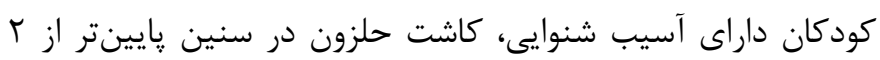

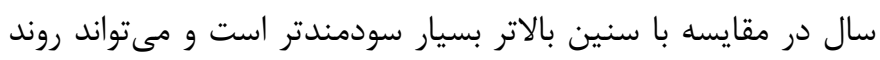
رشد شنوايى، زبانى و كفتارى در اين كودكان را تسريع نمايد (ه، و).

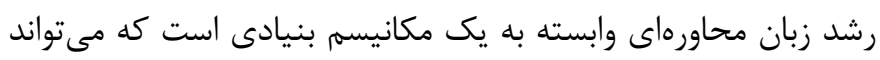
درون دادها را سازماندهى كند (V). اين مكانيسم، يادكيرى توالى يا

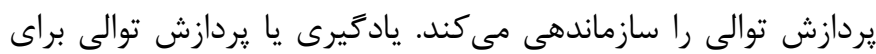
فراگيرى الكَوهاى سازماندهى شده در زمينههايى مثل زبان و ارتباطات، يادكيرى مهارتهاى حركتى، درى و توليد موسيقى، حل مسأله و

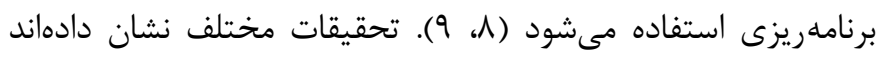

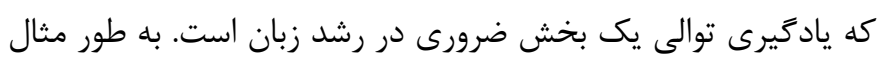

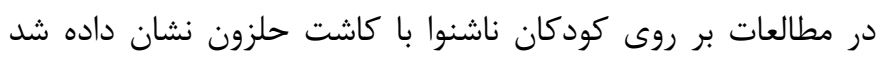

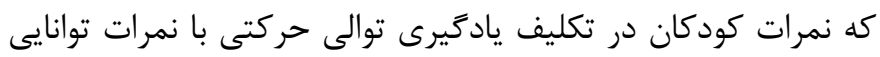
زبانى آنها در هجا (^-• (1) و رمزتردانى واجى (1 (1) مرتبط است.

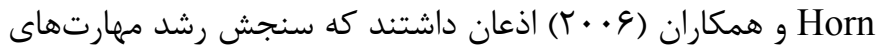
حركتى ظريف قبل از كاشت حلزون مىتواند رشد مهارتهاى زبان محاورهاى در كودكان بعد از كاشت حلزون را يُشبينى كند (IT).

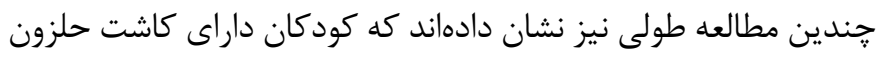

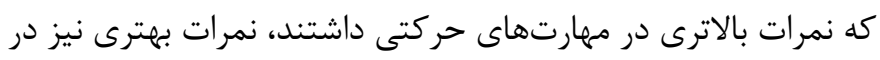

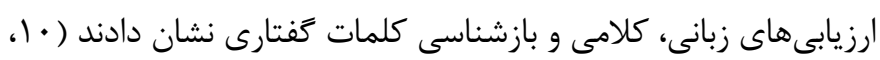

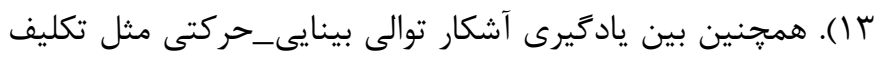

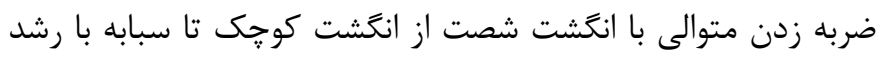

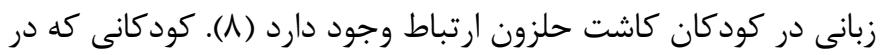
اجراى اين تكليف مشكل داشتند از نظر مهارت زبانى نيز ضعيف بودند. جرا كه به نظر مىرسد ناشنوايى منجر به تغيير الكوى طبيعى نيمكره 
تشخيص قافيه): در خرده آزمون تشخيص تجانس آزمونكر از آزمودنى

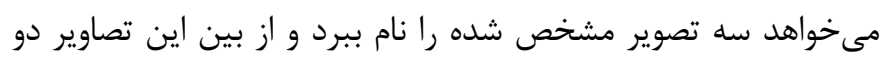

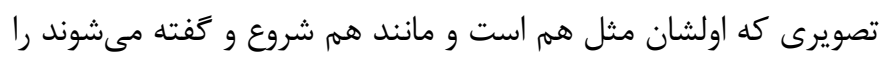

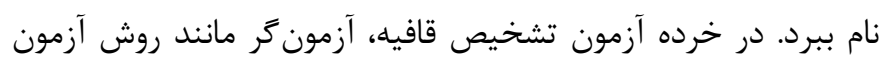

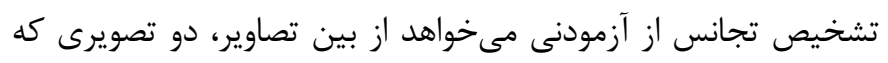

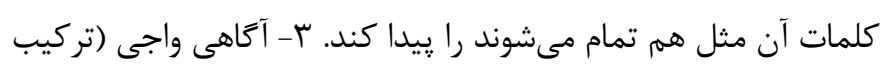

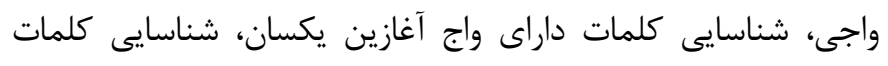

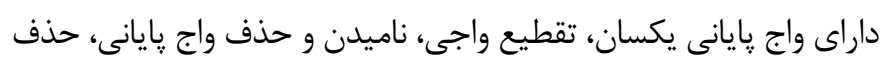

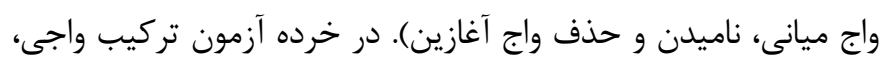

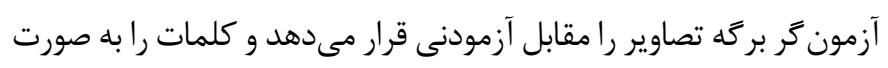

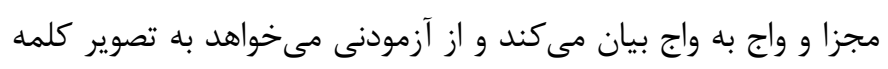

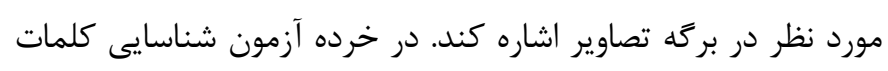

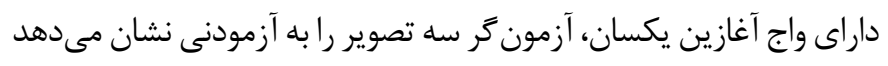

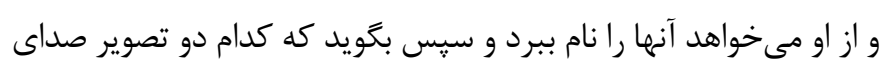

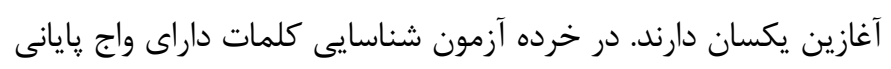
يكسان، ماند خرده آزمون آغازين يكسان است با اين تفاوت كه آزمودنى دانى داني

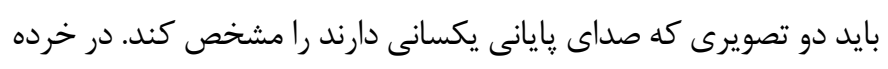

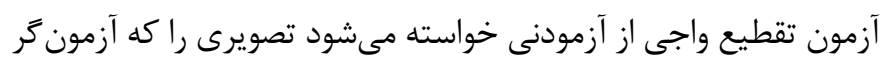

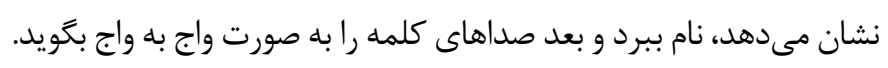

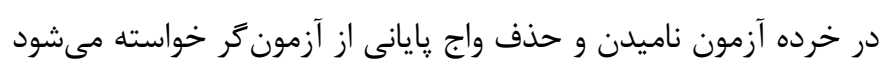

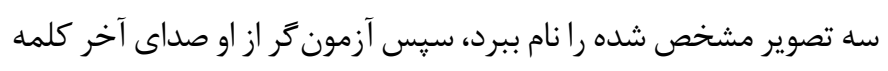

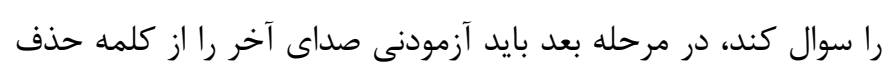

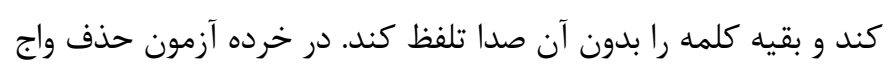

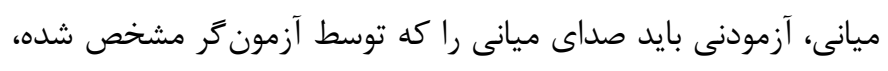

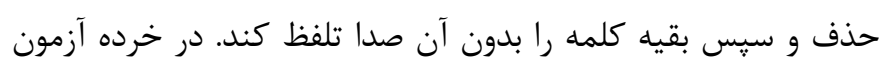

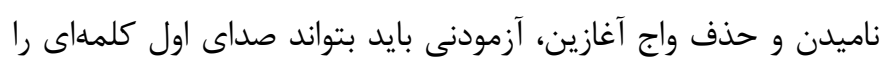

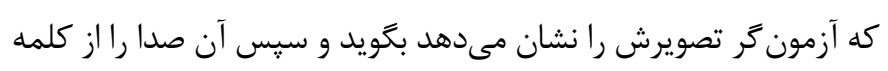

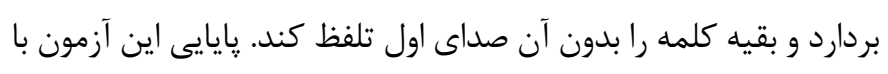

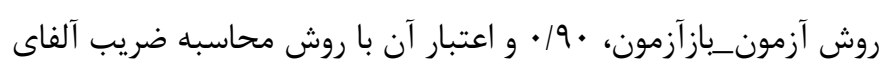

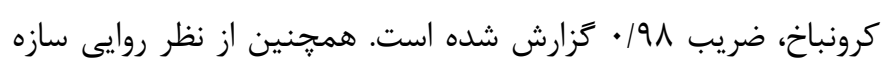

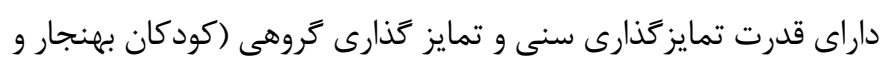

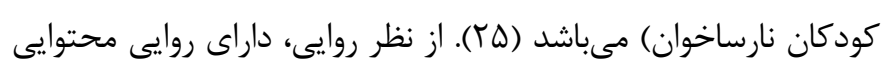

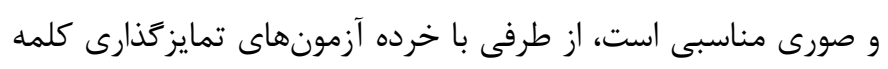

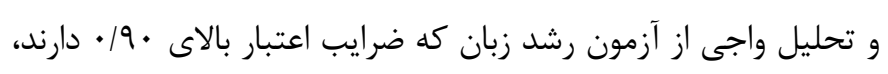

همبستكى بالايى را نشان داده است (روايى ملاكى) (ع) آند).

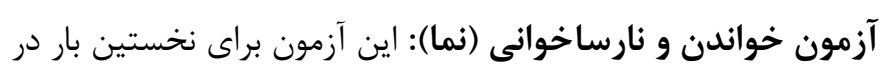

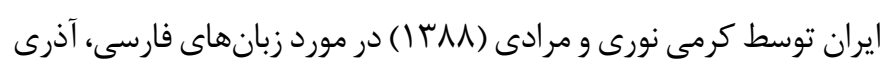

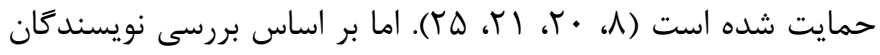

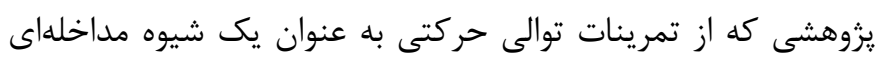

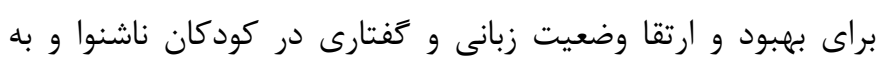

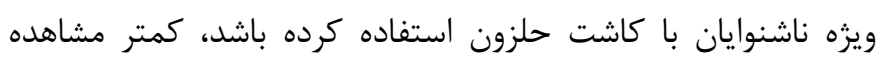

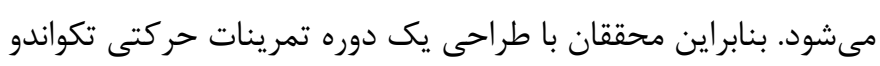

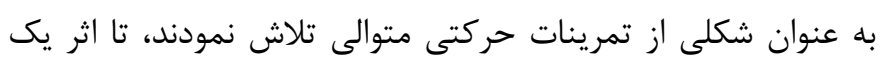

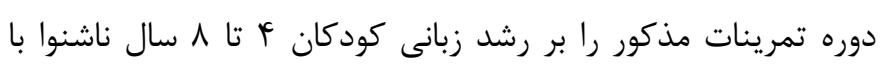

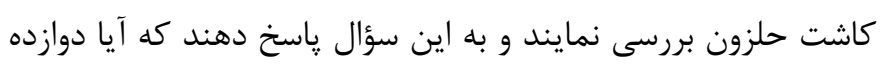

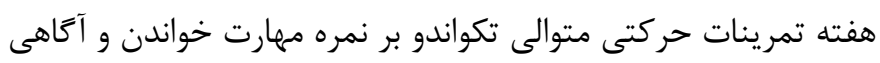

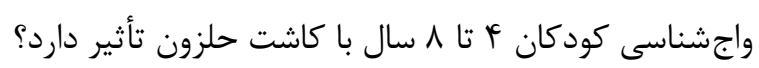

\section{روش كار}

اين يزوهش از نوع نيمه تجربى با طرح ييش آزمون_بس آزمون و كروه كنترل بود. شركت كنند

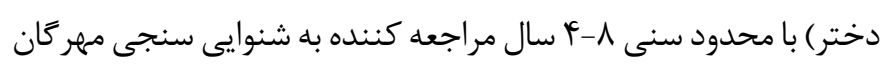

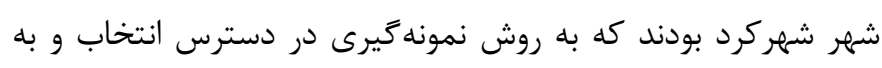

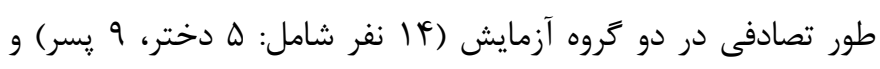

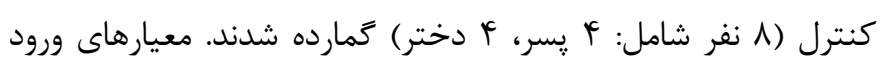

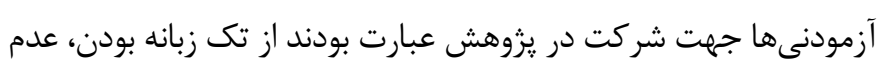

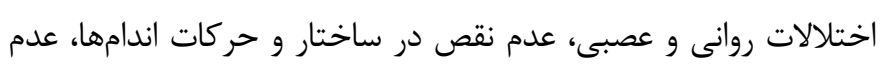

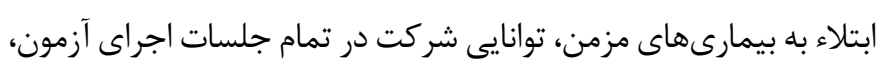

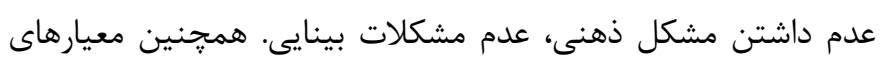

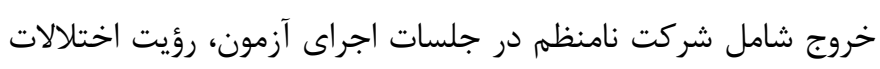

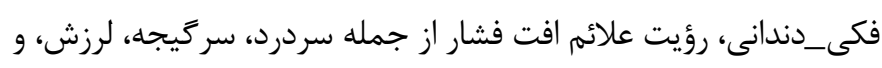

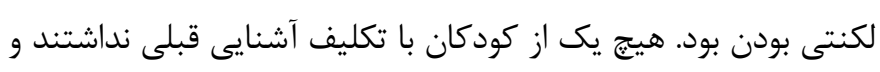
جهت شركت در تحقيق فرم رضايتنامه توسط والدين آنها تكميل گرديد.

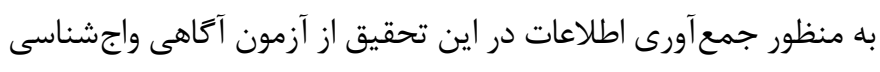

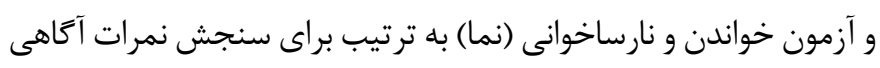
واجشناسى و عملكرد خواندن استفاده شد. آزمون آتاهى واجى شناسى: اين آزمون توسط سليمانى و دستجردي إدهى

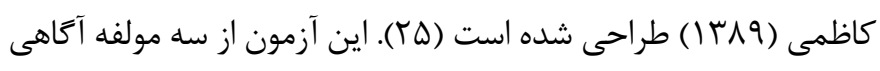

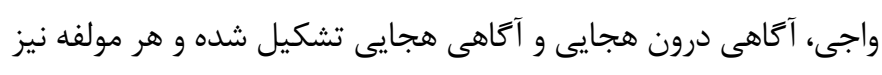

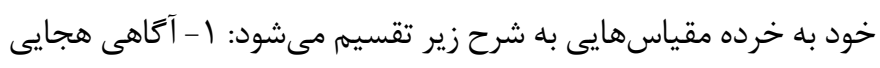

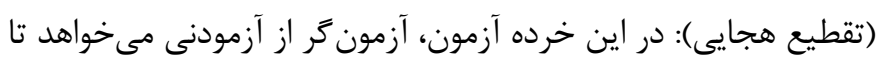

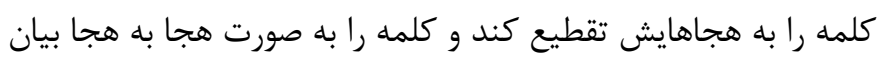

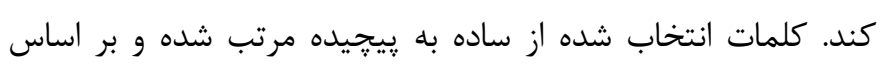

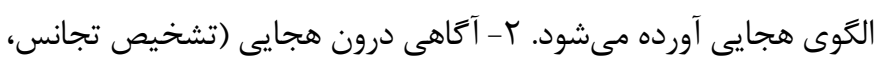


تمرين را با نمايش دادن فيلم كوتاه، سيس به صورت كلامى به كودكان آموزش مىداد. تمرينات در ابتدا از حركات ساده دست شروع مىشد و سيس با تركيب حركات يا كه يشت هم صورت مى گرفت و مشكلتر مىشد، ادامه مىيافت. در اين مدت گروه كنترل فعاليتهاى روزمره زندكَى خود را دنبال مى كردند. بعد از اتمام دوره تمرينى مجددا هر دو گروه ارزيابى شدند (يس آزمون). به منظور آزمون فرضيههاى يزوهش ضمن كنترل اثر ييش آزمون از آناليز كوواريانس استفاده شد. لازم به به آنه ذكر است قبل از انجام اين آزمون، فرض نرمال بودن، همگونى واريانس

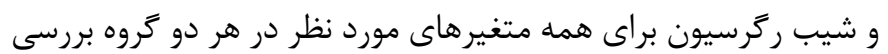

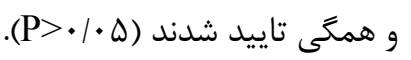

\section{يافته ها}

بر اساس يافتههاى جدول ا، نتايج تحليل كوواريانس نشان داد با كنترل عامل ييشآزمون، مقدار F جهت تفاوت بين دو زروه معنادار است. بدين معنا كه تفاوت معنادارى بين نمرات آخاهى واجشناسى در كودكان دو گروه مشاهده شد و ميانگين نمرات گروه آزمايش به طور

$$
\text { معنادارى نسبت به گروه كنترل بيشتر بود. }
$$

بر اساس يافتههاى جدول r r، نتايج تحليل كوواريانس نشان داد با كنترل عامل ييشآزمون، مقدار F جهت تفاوت بين دو گروه معنادار است. بدين معنا كه تفاوت معنادارى بين نمرات عملكرد خواندن در كودكان دو گروه مشاهده شد و ميانگين نمرات گَروه آزمايش به طور معنادارى نسبت به گروه كنترل بيشتر بود.
و كردى گردآورى شده است (YV). اين آزمون داراى • ا خرده آزمون (خواندن كلمات، زنجيره كلمات، خرده آزمون قافيه، ناميدن تصاوير،

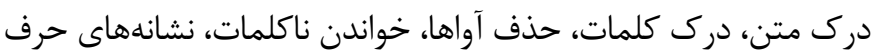
و نشانههاى مقوله) است كه نحوه اجرا و نمره گذارى آنها متفاوت است.

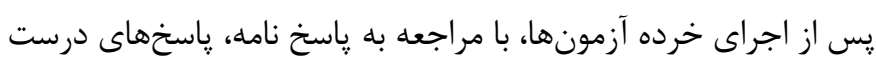
آزمودنى در هر خرده آزمون مشخص و نمره خام وى محاسبه ميى لَّود. نمرات خام را در ياسخ نامه و همجنين در بر گه خلاصه وضعيت خواندن آزمون، يادداشت مى گردد. با مراجعه به جداول مربوط به هر خرده آزمون در هر يايه نمرات تراز شده محاسبه مىشود و نيمرخ آزمودنى در اين

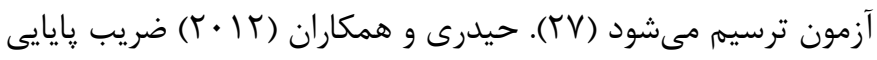
آزمون خواندن و نارساخوانى را با استفاده از روش آلفاى كرونباخ براى

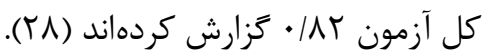
روش اجرا: به اين صورت بود كه يك هفته قبل از شروع تمرينات از هر دو گروه آزمونهاى خواندن و نارساخوانى و آًَاهى واج شناختى گرفته شد (ييش آزمون). سيس گروه آزمايش يك دوره تمرينات متوالى تكواندو را تمرين كردند. تمرينات تكواندو به مدت دوازده هفته (س جلسه در هفته) بود كه هر جلسه ه\& دقيقه به طول مى انجاميد. اين تمرينات از حركات دفاعيه تكواندو كه بصورت متوالى پشت سر هم صورت مى باز كننده يايين، دفاع دو ضربه، دفاع دوتايى بالا، ضربه با تيغه دست، ضربه با تيغه دو دست بود، تشكيل مىشد (ج)). براى آموزش و نظارت بهتر تمرينات از مربى متخصص تكواندو كودكان استفاده شد. مربى هر

\begin{tabular}{|c|c|c|c|c|c|c|}
\hline مجذور اتا & $\mathrm{P}$ & $\mathrm{F}$ & ميانگين مربعات & درجه آزادى & مجموع مربعات & منبع تغيير \\
\hline.$|9|$. & $* \cdot 1 \cdot \cdot 1$ & $r q / 9 \Delta V$ & $19 \Delta 9 / 499$ & 1 & $19 \Delta 9 / 499$ & بين كَروهى \\
\hline \multirow[t]{2}{*}{ - $/ \Lambda \Delta F$} & $* \cdot / \cdot 1$ & $11 \cdot / 911$ & $g r I \cdot / \cdot \Delta r$ & 1 & grI./. $\Delta r$ & ييش آزمون \\
\hline & & & $\Delta \Delta / १ \Delta \varphi$ & 19 & $1.94 / 191$ & خطا \\
\hline
\end{tabular}
جدول ا. نتايج آناليز كوواريانس نمرات بِ آزمون آَاهى واجشناسى بين دو گروه

$* \mathrm{P}<\cdot / \cdot \Delta$

\begin{tabular}{|c|c|c|c|c|c|c|}
\hline مجذور اتا & $\mathrm{P}$ & $\mathrm{F}$ & ميانگين مربعات & درجه آزادى & مجموع مربعات & منبع تغيير \\
\hline$\cdot / r \cdot 1$ & $* \cdot 1 \cdot k T$ & F/VGG & 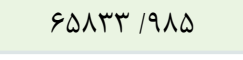 & 1 & 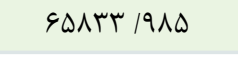 & بين كروهى \\
\hline \multirow[t]{2}{*}{$\cdot|r 9|$} & $* \cdot 1 \cdot 11$ & S/VID & QTVDD/FTr & 1 & qTVDD/FrT & ييش آزمون \\
\hline & & & ITAIT/KTV & 19 & TETFAI /T. & خطا \\
\hline
\end{tabular}

جدول rا. نتايج آناليز كوواريانس در بررسى امتيازات پِ آزمون عملكرد خواندن بين دو كروه

$* \mathrm{P}<\cdot / \cdot \Delta$ 
اين ويزگى صدا كه در بردارنده مفهوم زمان است مىتواند بيان كننده اين نكته مههم باشد كه نداشتن تجربه آوايى مى تواند علاوه بر تاثيرات واضحى كه بر روى حس شنوايى دارد تاثير بسيار عميقترى بر رشد شناختى داشته باشد. همجنين مطالعات نشان دادهاند كه ناشنوايى نه تنها مىتواند بر روى يادگيرى محركهاى زنجيرهاى تاثير بكذارد، بلكه

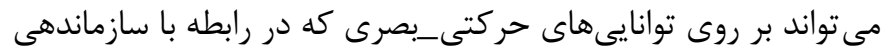

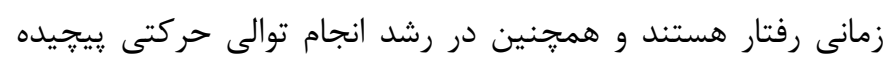

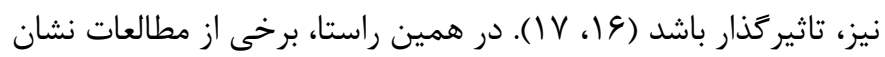

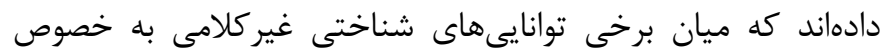
آنهايى كه در سازماندهى زمانى رفتار دخيل هستند و رشد توانايىهاى كَفتارى افراد ناشنوايى كه كاشت حلزون داشتهاند ارتباط مستقيمى لنائ

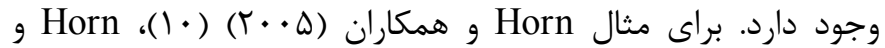

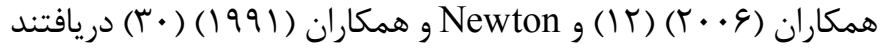
كه ميزان رشد حركتى ظريف قبل از كاشت حلزون مىتواند نشان مانر

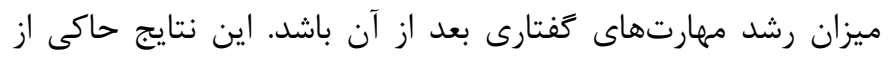

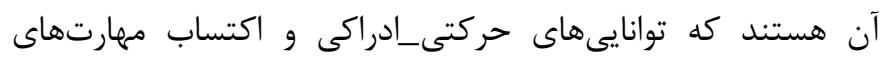

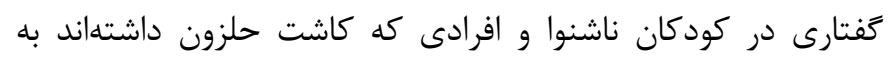
Carello طور مستقيمى با يكديخر در ارتباط هستند. در همين راستان

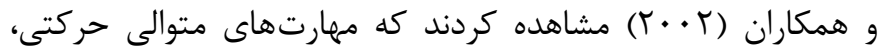
ماند ضربه زدن با انگشت با مهارت خواندن در افرادى كه اختلالات خواندن داشتند، رابطهى مستقيمى دارد. اين امر مىتواند به اين معنا باشد كه مهارتهاى متوالى غيركلامى با رشد زبانى به صورت كلى

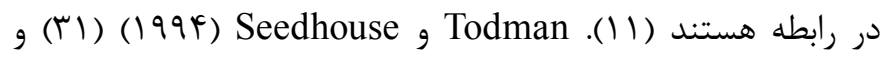
I و همكاران (Y Schlumberger

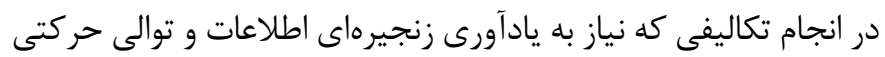

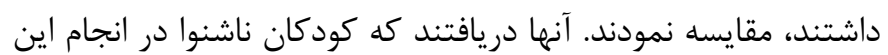
تكاليف بسيار ضعيفتر از كودكان شنوا عمل كردند. اين نتايج نشان مى دهند كه كودكان ناشنوا، دجار اختلال در كدگذارى و به يادآورى زنجيرهاى مطالب در حافظه و انجام توالى حركتى مىباشند. مطالعات اخير توانستهاند ميان كنترل و هماهنكى حركتى و و

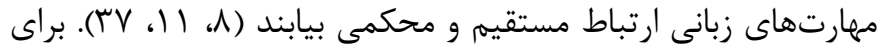

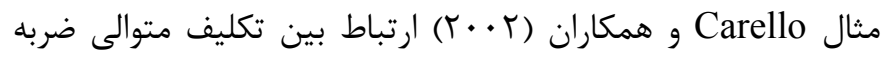

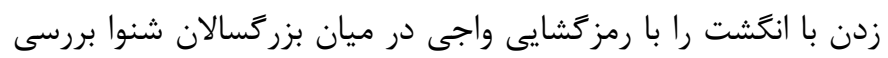

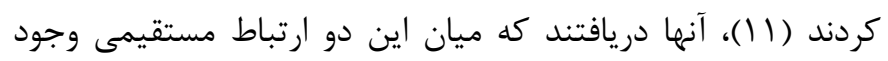

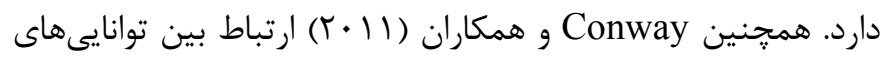
شناختى كلامى و غير كلامى را ميان كودكان شنوا و كودكان ناشنوايى كه كاشت حلزون داشتند، بررسى كردند و به اين نتيجه رسيدند كه
هدف از يزوهش حاضر بررسى اثر يك دوره تمرينات حركتى متوالى بر رشد زبانى كودكان ₹ أنا 1 سال ناشنواى كاشت حلزون بود. نتايج يزوهش حاضر نشان داد بين مهارتهاى حركتى و زبانى، بهبود

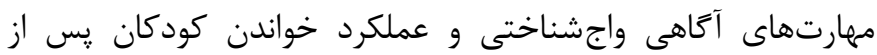
دوازده هفته تمرينات حركتى متوالى تكواندو ارتباط وجود دارد. اين

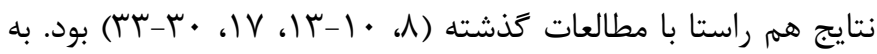
نظر مىرسد وجود زير بناى نظرى در زمينه پِيوند بين، حس شنوايى با ادراى زمان و ترتيب سريالى توجيه كننده مناسبى براى مشاهده اين اتفاق باشد (YY). طبق :زوهش هاى اخير محروميت آوايى ممكن است منجر به بروز اختلالات ثانويه در جنبههايى از شناخت غيركلامى بلى بشود. به خصوص در مهارتهايى كه مربوط به تظاهر و يا سازماندهى توالى الكوهاى ديدارى و ديدارى_حركتى هستند (9). از آنجايى كه صوت در حقيقت سيكنالى است با ماهيت زمانى، اين احتمال وجود دارد كه عدم دسترسى به ورودىهاى متوالى در مراحل اوليه رشد باعث عدم رشد كافى فرآيندهاى عصبى_شناختى مربوط به كدگذارى و تظاهر الكوهاى متوالى گردد. با در نظر كرفتن اين موضوع مى توان مرندان كفت كه صوت ممكن است به صورت لاداربسته و يا به بيان ديكر يك جارجوب حمايتى براى يردازش ورودىهاى زنجيرهاى عمل كند، بنابراين محروميت آوايى مىتواند يِامدهاى منفىاى بر روى كدَذارى، تظاهر، و توليد دوباره الكوهاى زنجيرهاى داشته باشد (9). نتايجى كه از

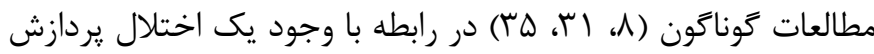
متوالى در افراد ناشنوا نه تنها در زمينه مهارتهاى حركتى و زبانى بلكه در زمينههاى مختلف ديكر به دست آمده است، مىتواند مدركى در

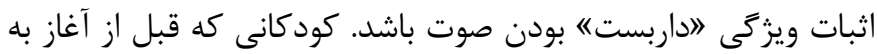
تكلم ناشنوا بودهاند و پس از آن كاشت حلزون داشتهاند اين محروميت آوايى را تجربه كردهاند و پِ از كاشت حلزون در كسب برخى مهارتهاى زبانى از خود تاخير نشان مىدهند. همين كودكان دجار اختلالاتى در اجراى مهارتهاى حركتى به خصوص تعادل، هماهنكى آنى جشم و دست، دويدن، و يرتاب نيز هستند (91). همانكونه كه در بالا اشاره شد، حس شنوايى به طور مستقيم مرتبط با زمان و ادراك ترتيب درني سريالى مىباشد (Y (T). در اين صورت اكر در ابتداى مراحل رشد، تجربه آوايى وجود نداشته باشد، كاركردهاى شناختى مانند ادراك، دستكارى، و سازماندهى توالىهاى زمانى محركهاى غير كلامى مى توانند تحت تاثير قرار بخيرند. مىتوان كفت كه افراد با اختلالات شنوايى تجربه كمى در رابطه با ويزگكىهاى آوايى عادى كه نشان دهنده كذشت زمان هستند دارند، به طور مثال تيك تيك ساعت و يا زنگ تلفن (צ؟). 
سيستم رشد زبانى و حركتى به ظاهر مستقل، تحت تاثير فرآيندهاى بلوغ و تمايز بيولوزيكى و رنى يكسانى قرار دارند (1). يافتهاى اخير شناختى به اين نتيجه رسيدهاند كه مكانيسمهاى

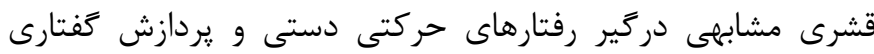

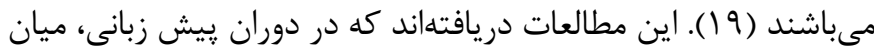

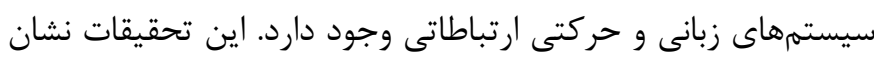
دادهاند كه مناطق مغزى دركير در حركات ريتميك اندامها، همان

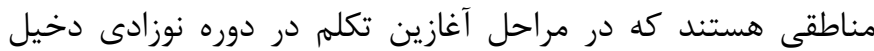
هستند (ז ا، ץץ). Locke و همكاران حركات ريتميك دست را در نوزادان سالم بررسى كردند و متوجه شدند نوزادانى كه آغاز راست دست شدن را از خود نشان دادند، همان نوزادانى بودند كه وارد اولين مرحله تكله شده بودند. بر اساس اين يافته، محققان به اين نتيجه رسيدند كه ناحيهاى مشترك در قسمت نيمكره جٍ مغز در انجام حر كات ريتميك

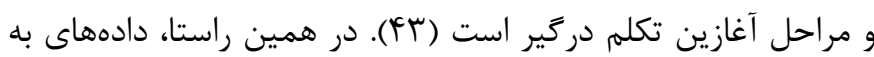

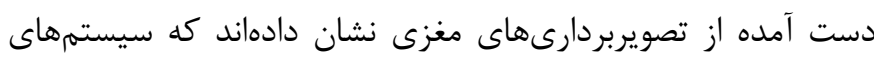

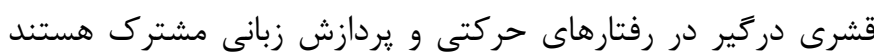

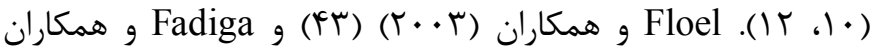

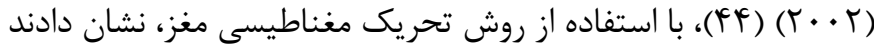
كه قشر حركتى هنحام گوش كردن به يك مطلب فعال مىشود، اين

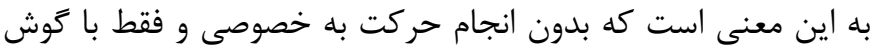
كردن به يك مطلب، آن قسمت از مغز كه مخصوص حركات بدن در موقع صحبت كردن است، تحريك مى شود. در مطالعه ديگرى، Fadiga و همكاران دريافتند كه قشر حركتى، درهنغام گوش كردن به لغتهاى

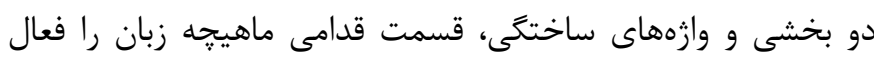
مى كند و اين رويدادى بود كه در هنكام كوش كردن به محرك فه فهاى

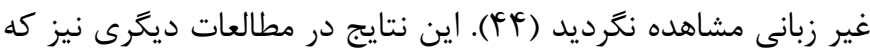
بر روى جنبههاى ديكر كلام و يردازش زبانى بودهاند، تكرار شده است

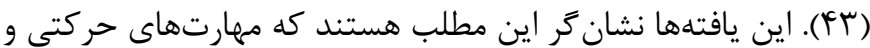
سيستمهاى زبانى به صورت مستقيمى با يكديكر مربوط هستند و اين ارتباط ناشى از اين حقيقت است كه براى تكلم كردن نياز است كه به برخى اندامها (براى مثال زبان، فك، و...) به حركت درآيند. Wilson

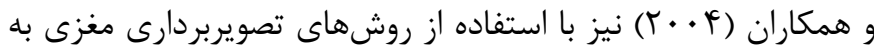

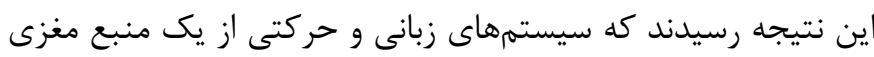

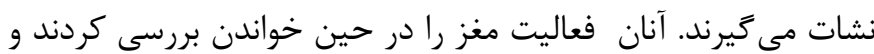
دريافتند كه قسمتهاى ييش حركتى مغز در حين خواندن فعال شدند (5ه). همجنين نشان دادند كه قسمتهاى حركتى قشر مغز در حين كوش كردن به جملاتى كه از لحاظ معنى واضح و يا نامفهوم بودند،
مهارتهاى كلامى ارتباط مستقيمى با مهارتهاى شناختى غير كلامى به خصوص توانايىهاى توالى دار دارند (^). مطالعات ديخر همجنين ارتباط مستقيمى بين اختلالات خواندن و مهارتهاى هماهنكى و والى

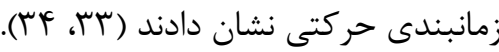

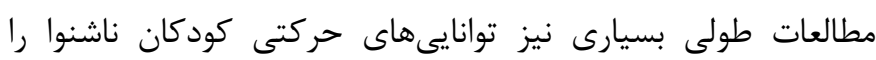
قبل و بعد از كاشت حلزون مورد مقايسه قرار دادهاند. اين مطالعات نشان دادهاند كودكانى كه از توانايىهاى حركتى بهترى برخوردار بودند، نمراتشان در آزمونهاى توانايىهاى زبانى به مراتب بيشتر از كودكانى بود كه توانايىهاى حركتى ضعيفترى داشتند (• (1، II). (199V) Broesterhuizen و كلامى در ناشنوايان وابسته به توانيىهايى هستند كه مربوط به يادكيرى و اجراى حركات متوالى دست و دهان مى باشند (r).

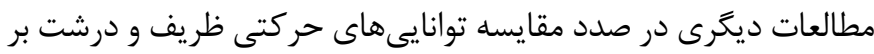

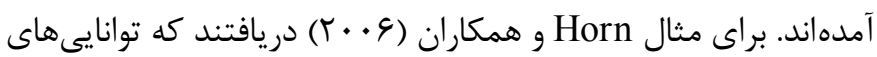
حركتى ظريف به طور مستقيمى با توانايى هاى كفتارى و شنيدارى زبان (بنان در رابطه هستند (r) (). با در نظر كرفتن اين نتايج مى توان نتيجه كرفت كه ارتباط مستقيمى ميان رشد مهارتهاى حركتى و يردازش زبانى وجود دارد كه بيان تا حدودى وابسته به برخوردارى از رشد بىعيب مهارتهاى حركتى مىباشد (^). درك بهتر ارتباطى كه ميان مهارتهاى توالى دار و زبان وجود دارد را مى توان از لحاظ بالينى نيز مورد بررسى قرار داد. زيرا اين موضوع در فهم بهتر تفاوتهاى موجود در مهارتهاى زبانى قبل

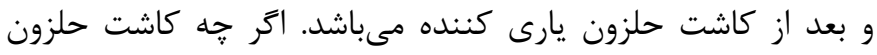
به عنوان يك روش موثر درمانى براى رشد مهارتهاى كفتارى زبان

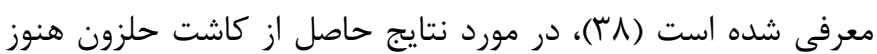
اتفاق نظر وجود ندارد. يكى از دلايل اين عدم اتفاق نظر بررسىهاى محدود فاكتورهاى عصبى_شناختى زيربنايى جون فر آيندهاى زيربنايى

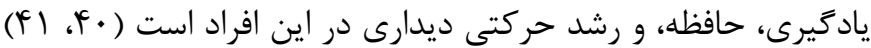
مطالعات اخير نشان دادهاند كه يكى از اين فاكتورهاى زيربنايى كه

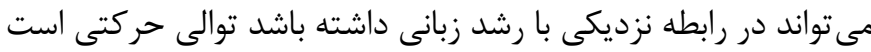

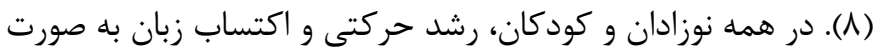

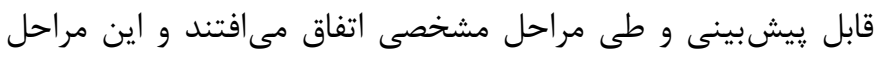
مشخص بين سيستمهاى يردازشى مختلف مشترك هستند؛ به طور مثال ظهور برخى از علائم رشد زمانى، با ظهور برخى از علائم رشد مداني حركتى همزمان هستند ( أl). علاوه بر اين، نشان داده شده است كه مراحل اوليه رشد حركتى مىتواند نشانكر خوبى براى رشد زبانى در

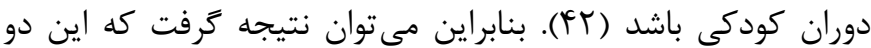


بهبود مهارتهاى آتاهى واجشناختى و عملكرد خواندن كودكان يس از دوازده هفته تمرينات حركتى متوالى تكواندو را نشان داد. بنابراين به نظر مىرسد ارتباط قوى ميان سيستمهاى زبانى و حركتى وجود داشته باشد و توجه به مداخلاتى با رويكرد حركتى براى بهببود مشكلات زبانى اين كودكان سودمند باشد. اميد است تا نتايج تحقيق حاضر بتواند به عنوان راهنمايى مورد استفاده دستاندر كاران رشد حركتى و توانبخشى قرار زيرد.

\section{تشكر و قدرواذى}

از مسئولين محترم مركز شنوايايى سنجى مهر گان شهر شهركرد و كليه

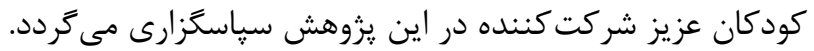

\section{References}

1. Ouellet C, Cohen H. Speech and language development following cochlear implantation. Journal of Neurolinguistics. 1999;12(3-4):271-288.

2. Movallali G, Afrooz GA, Hassan-Zadeh S, Malakooti B. Evaluation of the effects of Persian cued speech practice upon speech discrimination scores of hearing impaired children. $A u$ diol. 2010;19(2):39-46.

3. Peng SC, Tomblin JB, Turner CW. Production and perception of speech intonation in pediatric cochlear implant recipients and individuals with normal hearing. Ear and Hearing. 2008;29(3):336-351.

4. John K, Niparko M. Kids and cochlear implants: Getting connected. New York:Hopkins;2001.

5. Hassanali Fard M. Comparison between auditory and speech ability of cochlear implanted children. Kowsar Medical Journal. 2011;15(4):233-237. (Persian)

6. Zamani P, Daneshmandan N, Salehi A, Rahgozar M. Comparison of Persian simple vowels production in cochlear implanted children based on implantation age. Archives of Rehabilitation. 2008;9(2):59-65. (Persian)

7. Gervain J, Mehler J. Speech perception and language acquisition in the first year of life. Annual Review of Psychology.

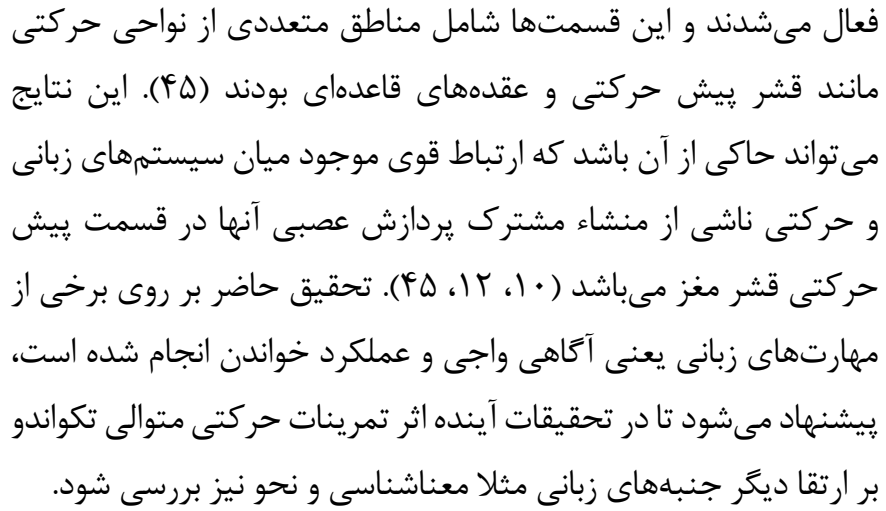

\section{0;61:191-218}

8. Conway CM, Pisoni DB, Anaya EM, Karpicke J, Henning SC. Implicit sequence learning in deaf children with cochlear implants. Developmental Science. 2011;14(1):69-82.

9. Conway CM, Pisoni DB, Kronenberger WG. The importance of sound for cognitive sequencing abilities: The auditory scaffolding hypothesis. Current Directions in Psychological Science. 2009;18(5):275-279.

10. Horn D, Pisoni D, Sanders M, Miyamoto R, Behavioral. Assessment of prelingually deaf children priorto cochlear implantation. The Laryngoscope. 2005;115(9),1603-1611.

11. Carello C, LeVasseur VM, Schmidt RC. Movement sequencing and phonological fluency in (putatively) nonimpaired readers. Psychological Science. 2002;13(4):375-379.

12. Horn DL, Pisoni DB, Miyamoto RT. Divergence of fine and gross motor skills in prelingually deaf children: implications for cochlear implantation. The Laryngoscope. 2006;116(8):1500-1506.

13. Broesterhuizen M. Psychological assessment of deaf children. Scandinavian Audiology. Supplementum. 1997;46:43-49.

14. Bishop DV. Motor immaturity and specific speech and language impairment: Evidence for a common genetic basis. 
American Journal of Medical Genetics. 2002;114(1):56-63.

15. Powell RP, Bishop DV. Clumsiness and perceptual problems in children with specific language impairment. Developmental Medicine \& Child Neurology. 1992;34(9):755-765.

16. Savelsbergh GJ, Netelenbos JB, Whiting HT. Auditory perception and the control of spatially coordinated action of deaf and hearing children. Journal of Child Psychology and Psychiatry. 1991;32(3):489-500.

17. Schlumberger E, Narbona J, Manrique M. Non-verbal development of children with deafness with and without cochlear implants. Developmental Medicine and Child Neurology. 2004;46(9):599-606.

18. Sevinc S, Ozcebe E, Atas A, Buyukozturk S. Articulation skills in Turkish speaking children with cochlear implant. International Journal of Pediatric Otorhinolaryngology. 2009;73(10):1430-1433.

19. Conway CM, Bauernschmidt A, Huang SS, Pisoni DB. Implicit statistical learning in language processing: Word predictability is the key. Cognition. 2010;114(3):356-371.

20. Miyamoto RT, Robbins AM, Svirsky M, Todd S, Kirk KI, Riley A. Speech intelligibility of children with multichannel cochlear implants. The Annals of Otology, Rhinology \& Laryngology. 1997;106(5):35-36.

21. Quittner AL, Leibach P, Marciel K. The impact of cochlear implants on young deaf children: new methods to assess cognitive and behavioral development. Archives of OtolaryngologyHead \& Neck Surgery. 2004;130(5):547-554.

22. Lashley KS. The problem of serial order in behavior. In: Jeffress LA, editor. Cerebral mechanisms in behavior. New York:Wiley; 1951.

23. Hall M, Eigsti I, Bortfeld H, Martin D, Auditory access, language access, and implicit sequence learning in deaf children. Developmental Science. 2018;21(3):e12575.

24. Liu QN. Analysis on the movement structure and characteristic of Taegeuk 3 Jang of taekwondo'spoomsae of popular taekwondo. Journal of Shaoyang University (Natural Science Edition). 2011;1:18.
25. Soleimani Z, Dastjerdi Kazemi M. The test of knowledge of phonology and its psychometric features. Tehran:Amozesh and Parvaresh Press the Study of Teaching and Training Institute;2010. (Persian)

26. Hasanzadeh Z, Minaei A. Adaptation and standardization of the test of TOLD-P: 3 for Farsi-Speaking children of Tehran. Journal of Exceptional Children. 2002;1(2):119-134. (Persian) 27. Karami R, Moradi R. Akbari S, Zahedian H. Reading and inaudible tests. Tehran:Jahad e Daneshgahi Press;2009.(Persian). 28. Heidari T, Amiri Sh, Molavi H. Effectiveness of Davis dyslexia correction method on reading performance of dyslexic children. Journal of Applied Psychology. 2012:6(22):4158. (Persian)

29. Taghvai M. Professional training of taekwondo: from basic to advanced. Tehran:Resaneh Maktoob;2018. (Persian)

30. Newton VE, Macharia I, Mugwe P, Ototo B, Kan SW. Evaluation of the use of a questionnaire to detect hearing loss in Kenyan pre-school children. International Journal of Pediatric Otorhinolaryngology. 2001;57(3):229-234.

31. Todman J, Seedhouse E. Visual-action code processing by deaf and hearing children. Language and Cognitive Processes. 1994;9(2):129-41.

32. Wolff PH, Michel GF, Ovrut M, Drake C. Rate and timing precision of motor coordination in developmental dyslexia. Developmental Psychology. 1990;26(3):349-359.

33. Wolff PH. A candidate phenotype for familial dyslexia. $E u$ ropean Child \& Adolescent Psychiatry. 1999;8(3):21-27.

34. Hirsh IJ. Information processing in input channels for speech and language: The significance of serial order of stimuli. In: Darley FL, editor. Brain mechanisms underlying speech and language. New York:Grune \& Stratton;1967.

35. Pisoni DB, Conway CM, Kronenberger W, Henning S, Anaya E. Executive function, cognitive control, and sequence learning in deaf children with cochlear implants. In: Marschark M. Spencer P, editors. Oxford handbook of deaf studies, language, and education. New York:Oxford University Press;2010. 36. Rileigh KK, Odom PB. Perception of rhythm by subjects 
with normal and deficient hearing. Developmental Psychology. 1972;7(1):54-61.

37. Gates G, Miyamoto R. Cochlear implants. New England Journal of Medicine. 2003;349(5):421-423.

38. Pisoni D. Cognitive factors and cochlear implants: Some thoughts on perception, learning, and memory in speech perception. Ear and Hearing. 2002;21(1):70-78.

39. Pisoni DB, Conway CM, Kronenberger WG, Horn DL, Karpicke J, Henning S. Efficacy and effectiveness of cochlear implants in deaf children. In: Marschark M, Hauser P, editors.

Deaf cognition: Foundations and outcomes. New York:Oxford University Press;2008.

40. Lenneberg E. Biological foundations of language. New York:John Wiley \& Sons;1967.

41. Siegel LS, Saigal S, Rosenbaum P, Morton RA, Young A, Berenbaum S, et al. Predictors of development in preterm and full-term infants: a model for detecting the at risk child. Journal of Pediatric Psychology. 1982;7(2):135-148.

42. Locke J, Bekken K, Mc Minn Larson L, Wein D. Emergent control of manual and vocal-motor activity in relation to the development of speech. Brain and Language. 1995;51(3):498-508. 43. Floel A, Ellger T, Breitenstein C, Knecht S. Language perception activates the hand motor cortex: implications for motor theories of speech perception. European Journal of Neuroscience. 2003;18(3):704-708.

44. Fadiga L, Craighero L, Buccino G, Rizzolatti G. Speech listening specifically modulates the excitability of tongue muscles: a TMS study. European journal of Neuroscience. 2002;15(2):399-402.

45. Wilson SM, Saygin AP, Sereno MI, Iacoboni M. Listening to speech activates motor areas involved in speech production. Nature Neuroscience. 2004;7(7):701-702. 